Article

\title{
Harvestman Phenols and Benzoquinones: Characterisation and Biosynthetic Pathway
}

\author{
Daniele F. O. Rocha ${ }^{1}$, Felipe C. Wouters ${ }^{1}$, Dávila S. Zampieri ${ }^{1}$, Timothy J. Brocksom ${ }^{2}$, \\ Glauco Machado ${ }^{3}$ and Anita J. Marsaioli ${ }^{1, *}$
}

1 Instituto de Química, Universidade Estadual de Campinas, C.P. 6154, 13083-970 Campinas, SP, Brasil

2 Laboratório de Química Bio-Orgânica, Departamento de Química, Universidade Federal de São Carlos, Caixa Postal 676, 13565-905 São Carlos, SP, Brasil

3 Departamento de Ecologia, Instituto de Biociências, Universidade de São Paulo, Rua do Matão, trav.14, no. 321, 05508-090 São Paulo, SP, Brasil

* Author to whom correspondence should be addressed; E-Mail: anita@iqm.unicamp.br; Tel.: +55-19-3521-3067; Fax: +55-19-3521-3023.

Received: 19 July 2013; in revised form: 5 September 2013 / Accepted: 6 September 2013 / Published: 16 September 2013

\begin{abstract}
Benzoquinones are usually present in arthropod defence exudates. Here, we describe the chemical profiles of 12 harvestman species belonging to the neotropical family Gonyleptidae. Nine of the studied species produced benzoquinones, while three produced alkyl phenols. Two benzoquinones and one phenol exhibited biological activity against bacteria and fungi. We also studied the biosynthesis of 2-ethyl-1,4-benzoquinone by feeding Magnispina neptunus individuals with ${ }^{13} \mathrm{C}$-labelled precursors; the benzoquinones were biosynthesised through a polyketide pathway using acetate and propionate building blocks.
\end{abstract}

Keywords: chemical defence; NMR spectroscopy; arthropod biosynthesis; labelled precursors; evolution; chemotaxonomy; Opiliones

\section{Introduction}

Opiliones, which are commonly known as harvestmen or daddy longlegs, compose a large arachnid order with approximately 6,500 species widespread across the World [1]. The large neotropical family Gonyleptidae is chemically and morphologically diverse, comprising nearly 820 species [2]. 
Gonyleptid scent gland exudates are mainly composed of vinyl ketones and their hetero-Diels-Alder adducts [3-5], alkyl phenols [3,6-10] and benzoquinones [3,6,11-14].

In addition to harvestmen, naturally occurring 1,4-benzoquinones with great structural variety are also found in bacteria, plants and other arthropod orders $[15,16]$. They are known to be toxic and therefore are employed by beetles [17-20], earwigs [21], termites [22] and harvestmen [12,13] as a defence against natural predators. Additionally, their antimicrobial activity protects cockchafer larvae [23] and adult harvestmen [11] against pathogens, such as bacteria and fungi. The biosynthesis of 1-hepten-3-one produced by the harvestman Iporangaia pustulosa (Gonyleptidae) was recently described [24] as the condensation of one acetate and two propionate units following a polyketide pathway. However, there is no evidence of polyketide synthases (PKS) in harvestmen or in any other arthropod species studied so far [25]. These results claimed that additional evidence of PKS activities lay in the production of other classes of harvestman metabolites, such as benzoquinones.

We describe here the detailed chemical characterisation of the exudates for 12 gonyleptid species, which all contained mixtures of benzoquinones or alkyl phenols. Additionally, the biosynthetic pathway of the 2-ethyl-1,4-benzoquinone produced by Magnispina neptunus (Gonyleptidae) was investigated using ${ }^{13} \mathrm{C}$-labelled precursors.

\section{Results and Discussion}

\subsection{Chemical Profile of Gonyleptid Exudates}

The chemical compositions of 12 harvestman species-Bourguyia trochanteralis (Bourguyiinae), Chavesincola inexpectabilis, Magnispina neptunus (both Heteropachylinae), Discocyrtus oliverioi, Pachylus paessleri (both Pachylinae), Liogonyleptoides tetracanthus, Mischonyx cuspidatus (both Gonyleptinae), Metarthrodes longipes (Caelopyginae), Mitopernoides variabilis, Progonyleptoidellus striatus (both Progonyleptoidellinae), Multumbo terrenus (Hernandariinae) and Pachylospeleus strinati (Pachylospeleinae) - were investigated (Table 1). Nine of these species contained mainly mixtures of 1,4-benzoquinones in their scent gland exudate, while the other three produced alkyl phenols in higher abundance (Figure 1). All of the compounds have been characterised by mass spectrometry. Additionally, 2-methylbenzoquinone (6), 2-ethylbenzoquinone (7), 2,5-dimethylphenol (18) and 2,3,6-trimethylphenol (20) were fully characterised by ${ }^{1} \mathrm{H}$ - and ${ }^{13} \mathrm{C}-\mathrm{NMR}$ spectroscopy. Co-elutions with synthetic standards were used to confirm the presence of 4-methyl-1-hepten-3-one (1) [5], 1-methyl-1,4-benzoquinone (6) and 2,5-dimethyl-1,4-benzoquinone (8). Additionally, 2,5-dimethylphenol (18) was compared to a previously characterised natural sample.

\subsubsection{Benzoquinones Identification}

The benzoquinones' (6 to 13) mass spectra have intense molecular ions and characteristic fragmentation patterns, which feature $\mathrm{CO}$ and/or $\mathrm{C}_{2} \mathrm{H}_{2}$ loss (Figure 2) [26]. 
Table 1. Compounds detected in defensive secretion of gonyleptid harvestmen, ordered by retention index (RI).

\begin{tabular}{|c|c|c|c|c|}
\hline Structure & RI & Characteristic ions $[\mathrm{m} / z$ (abundance)] & Species & Relative abundance \\
\hline & 831 & $\begin{array}{c}112\left(\mathrm{M}^{+}, 15\right), 97(12), 84(35), 83(12), \\
69(12), 58(28), 56(23), 55(100), 41(29)\end{array}$ & Pachylus paessleri & $0.9 \%$ \\
\hline & 835 & $114\left(\mathrm{M}^{+}, 14\right), 85(10), 57(100), 41(14)$ & Mischonyx cuspidatus & $7.0 \%$ \\
\hline & $845 *$ & $\begin{array}{c}\text { 72(64), 71(19), 70(17), 57(19), 55(14), } \\
43(100), 41(21)\end{array}$ & Mischonyx cuspidatus & $0.2 \%$ \\
\hline & 929 & $\begin{array}{c}128\left(\mathrm{M}^{+}, 3\right), 99(11), 86(60), 71(82), \\
57(100), 55(13), 43(64), 41(16)\end{array}$ & Mischonyx cuspidatus & $2.8 \%$ \\
\hline 5 & $956^{*}$ & $\begin{array}{c}126\left(\mathrm{M}^{+}, 26\right), 111(49), 97(100) \\
83(21), 69(43), 67(21), 56(26), 55(63) \\
43(73), 41(78)\end{array}$ & Pachylus paessleri & $0.1 \%$ \\
\hline & 1010 & $\begin{array}{c}\left.\text { 124(45), 123(27), 122( } \mathrm{M}^{+}, 100\right), 94(64), \\
82(55), 68(31), 66(46), 54(55), 40(24)\end{array}$ & $\begin{array}{c}\text { Chavesincola inexpectabilis } \\
\text { Magnispina neptunus }\end{array}$ & $\begin{array}{l}10.1 \% \\
9.2 \%\end{array}$ \\
\hline 7 & 1103 & $\begin{array}{c}136\left(\mathrm{M}^{+}, 67\right), 123(16), 108(100), \\
107(42), 82(42), 80(18), 79(73), \\
77(15), 54(52), 53(30)\end{array}$ & $\begin{array}{c}\text { Magnispina neptunus } \\
\text { Chavesincola inexpectabilis }\end{array}$ & $\begin{array}{l}90.8 \% \\
80.2 \%\end{array}$ \\
\hline
\end{tabular}


Table 1. Cont.

\begin{tabular}{|c|c|c|c|c|}
\hline Structure & RI & Characteristic ions $[m / z$ (abundance)] & Species & Relative abundance \\
\hline & 1104 & $\begin{array}{c}138(14), 137(13), 136\left(\mathrm{M}^{+}, 100\right), 108(25) \\
96(20), 80(19), 79(37), 68(67)\end{array}$ & $\begin{array}{c}\text { Multumbo terrenus } \\
\text { Pachylus paessleri } \\
\text { Mischonyx cuspidatus }\end{array}$ & $\begin{array}{c}24.2 \% \\
10.3 \% \\
8.7 \%\end{array}$ \\
\hline & 1119 & $\begin{array}{c}136\left(\mathrm{M}^{+}, 100\right), 108(47), 107(47), 82(39) \\
80(17), 79(41), 54(37), 53(16)\end{array}$ & $\begin{array}{c}\text { Mischonyx cuspidatus } \\
\text { Bourguyia trochanteralis } \\
\text { Pachylospeleus strinati } \\
\text { Liogonyleptoides tetracanthus } \\
\text { Discocyrtus oliverioi } \\
\text { Pachylus paessleri } \\
\text { Chavesincola inexpectabilis }\end{array}$ & $\begin{array}{c}68.3 \% \\
65.0 \% \\
60.3 \% \\
58.6 \% \\
57.4 \% \\
53.2 \% \\
2.4 \%\end{array}$ \\
\hline $\mathrm{O}$ & 1182 & $\begin{array}{c}150\left(\mathrm{M}^{+}, 100\right), 135(10), 122(31), \\
121(16), 107(69), 82(20), 79(32), 77(16), \\
67(10), 54(18), 53(11)\end{array}$ & $\begin{array}{c}\text { Discocyrtus oliverioi } \\
\text { Liogonyleptoides tetracanthus } \\
\text { Bourguyia trochanteralis } \\
\text { Pachylus paessleri } \\
\text { Chavesincola inexpectabilis } \\
\text { Mischonyx cuspidatus } \\
\text { Multumbo terrenus }\end{array}$ & $\begin{array}{c}41.4 \% \\
39.9 \% \\
17.1 \% \\
4.6 \% \\
2.7 \% \\
1.3 \% \\
0.9 \%\end{array}$ \\
\hline O 11 & 1197 & $\begin{array}{c}150(\mathrm{M}+, 100), 137(14), 122(45), 121(14), \\
107(41), 82(13), 79(54), 77(17), \\
68(24), 54(13), 53(19)\end{array}$ & $\begin{array}{l}\text { Multumbo terrenus } \\
\text { Mischonyx cuspidatus } \\
\text { Pachylus paessleri }\end{array}$ & $\begin{array}{c}38.4 \% \\
9.3 \% \\
0.6 \%\end{array}$ \\
\hline
\end{tabular}


Table 1. Cont.

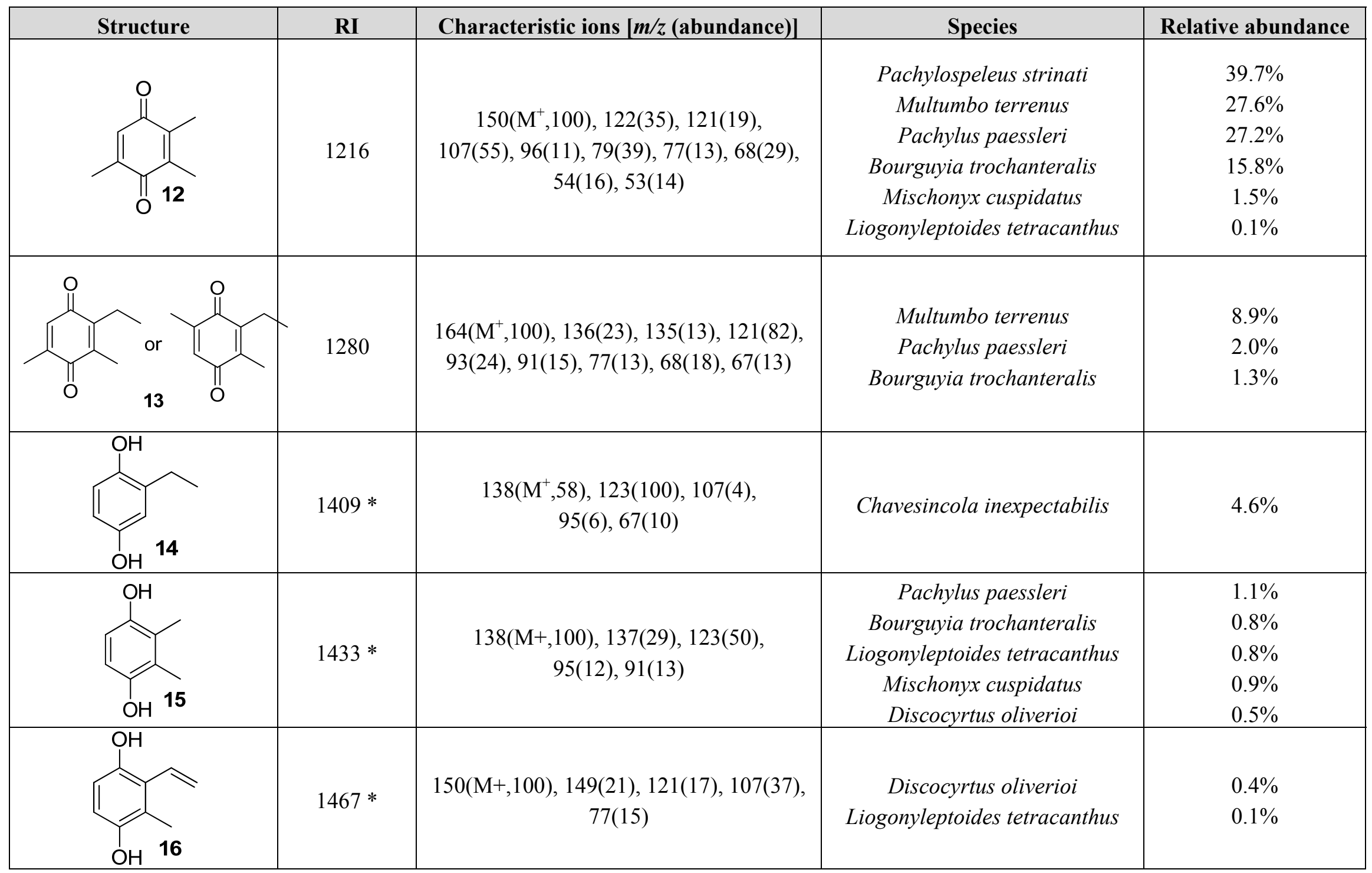


Table 1. Cont

\begin{tabular}{|l|l|c|c|c|}
\hline & RI & Characteristic ions [m/z (abundance)] & Species & Relative abundance \\
\hline & $1487 *$ & $\begin{array}{c}152\left(\mathrm{M}^{+}, 53\right), 151(11), 138(9), 137(100), \\
107(8), 79(10), 77(8)\end{array}$ & $\begin{array}{c}\text { Liogonyleptoides tetracanthus } \\
\text { Discocyrtus oliverioi }\end{array}$ & $0.5 \%$ \\
$0.3 \%$
\end{tabular}

* RI calculated from linear regression from data from the other compounds (see experimental details). 
Figure 1. Chromatograms of the harvestman exudates.
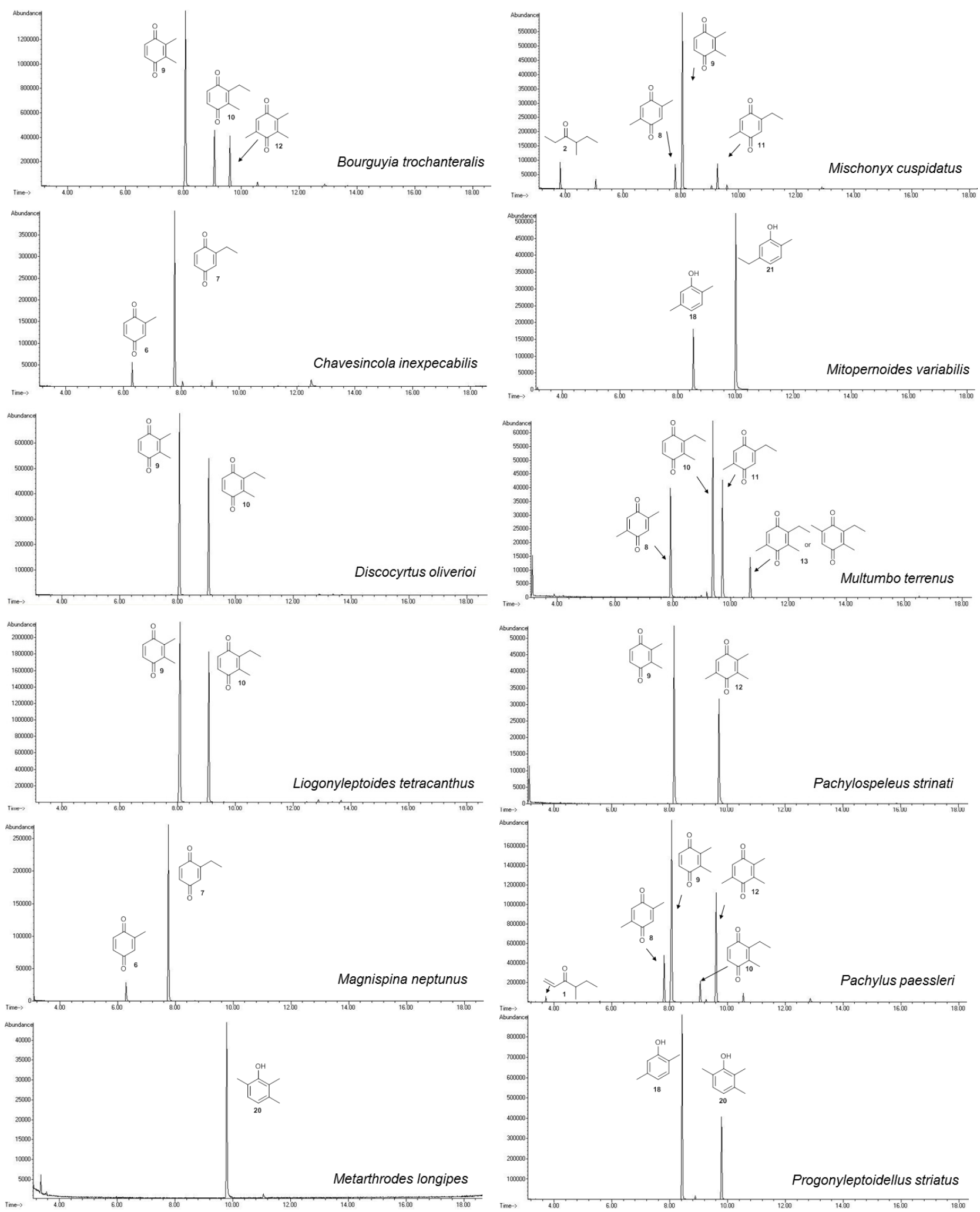
Figure 2. High-resolution mass spectra of benzoquinones from harvestman exudates.

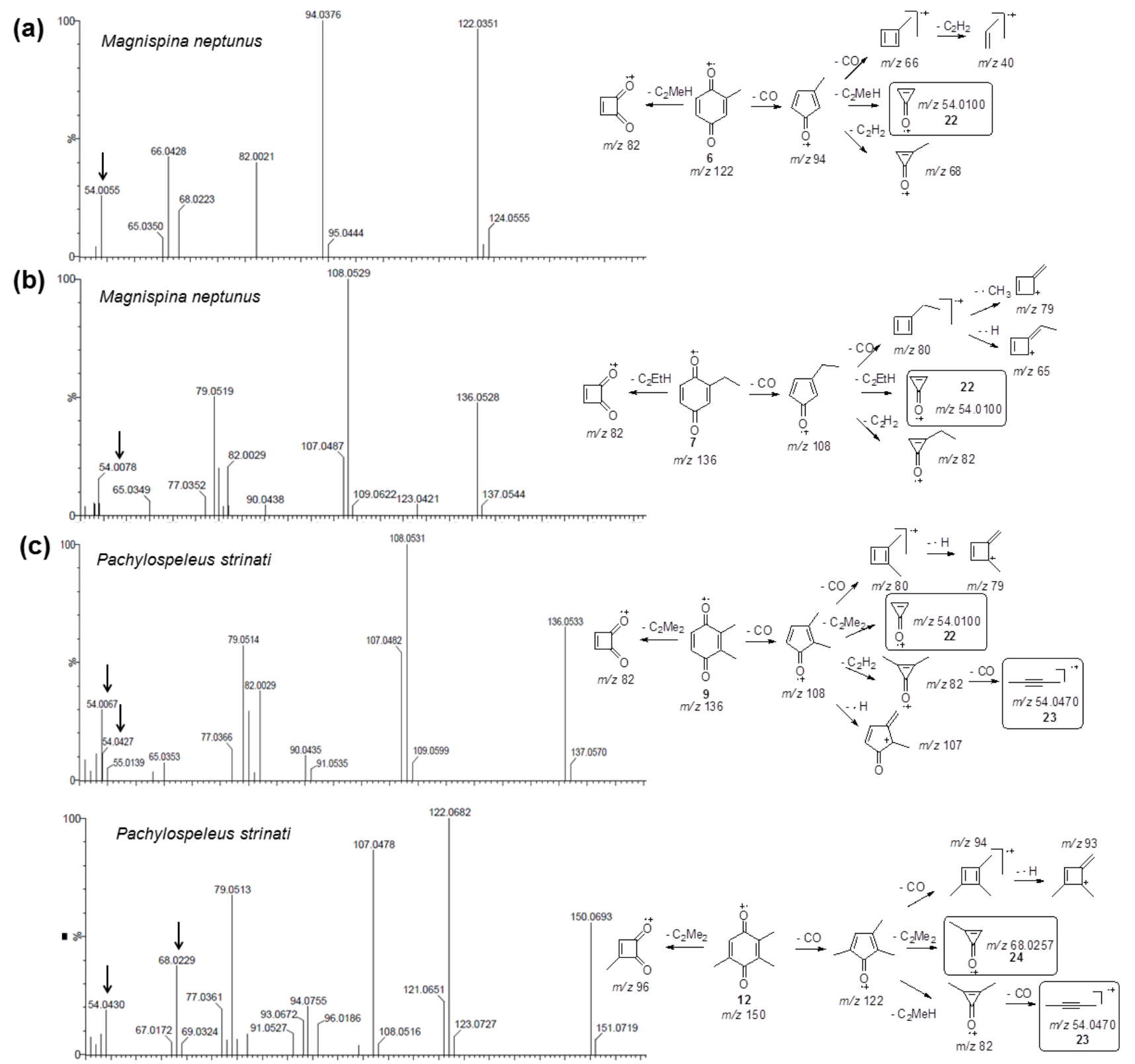

The exudate of Ma. neptunus was analysed by CG/TOF-MS; benzoquinones 6 and 7 displayed molecular ions at $m / z 122$ and 136, respectively (Figure 2a,b). The presence of a radical ion at $m / z 54$ ( 54.0055 for 6 and 54.0078 for 7) is characteristic of a cyclopropenone radical ion 22 (calculated mass 54.0100), signalling the presence of an asymmetric benzoquinone with substituents on one side of the ring. The benzoquinone present in Ps. strinati exudate (Figure 2c) has a molecular ion at $\mathrm{m} / \mathrm{z} 136$ and could possess either structure 9 or 7. However, the presence of the two fragments at $\mathrm{m} / z 54.0067$ (22) and at $\mathrm{m} / \mathrm{z} 54.0427$ (23) (calculated mass 54.0470) indicate that two methyl substituents are on the same side of the benzoquinone, confirming structure 9. Benzoquinone 12 (Figure 2d), however, has fragments at $\mathrm{m} / z 54.0430$ (23), indicating the presence of two methyl groups on C-2 and C-3, and at $\mathrm{m} / z$ 68.0229 (24) (calculated mass 68.0257), indicating the presence of a methyl group at C-5. This rationale was utilised to suggest benzoquinone structures $\mathbf{8 , 1 1}$ and $\mathbf{1 3}$, which also have methyl substituents at C-5. 
The ${ }^{1} \mathrm{H}-\mathrm{NMR}$ analyses of Ma. neptunus exudate revealed signals consistent with benzoquinones 6 and 7 (Figure 3); the methyl hydrogens at 2.07 ppm corresponded to minor benzoquinone 6 and the triplet at $1.15 \mathrm{ppm}$, when combined with the quartet at $2.47 \mathrm{ppm}$, was typical of the ethyl substituent assigned to major benzoquinone 7 [13]. The ${ }^{13} \mathrm{C}-\mathrm{NMR}$ spectra completed the spectroscopic characterisations of 6 and 7, except for the assignments of the carbons at the positions C-1/C-4 and C-5/C-6 of 7. Full structural assignment required 2D NMR experiments, such as HSQC and HMBC (Table 2 and Supporting Information). These data were essential for the biosynthetic experiment described below.

Figure 3. ${ }^{1} \mathrm{H}-\mathrm{NMR}$ spectrum (400.13 $\left.\mathrm{MHz}, \mathrm{CDCl}_{3}, \mathrm{TMS}\right)$ of Magnispina neptunus exudate containing benzoquinones $\mathbf{6}$ and 7 as major components: a-signals refer to benzoquinone 6 and b-signals refer to benzoquinone 7 .

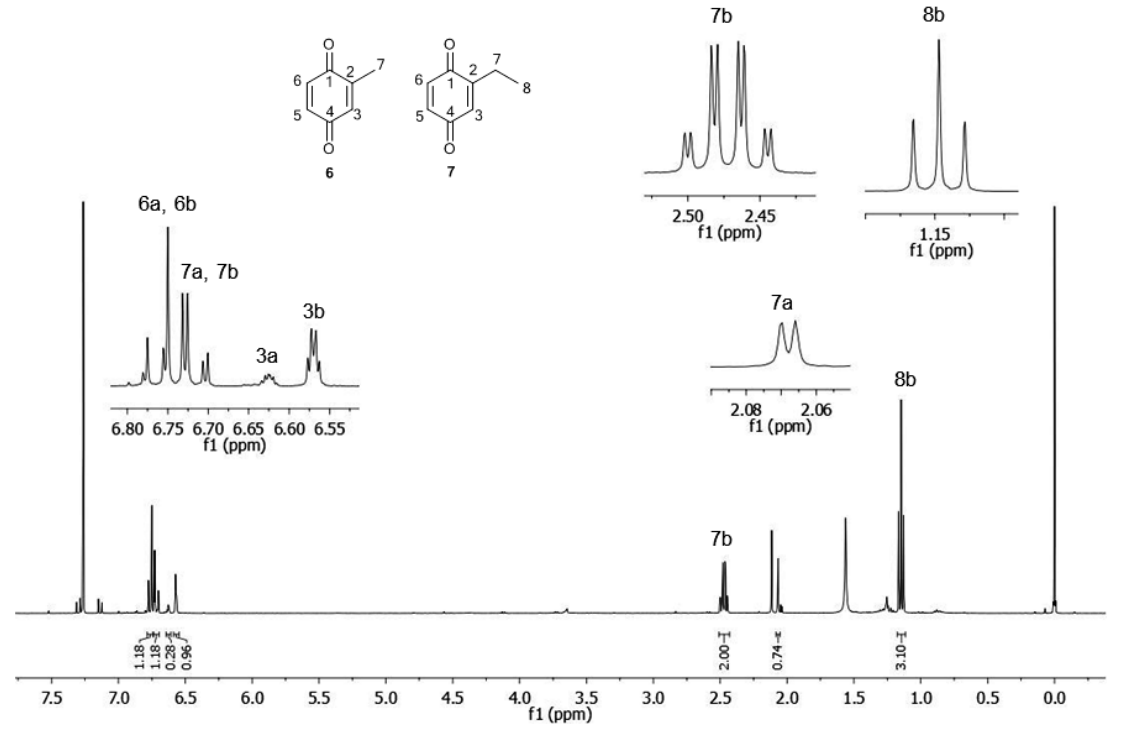

Table 2. NMR assignments for 2-methyl-1,4-benzoquinone (6) and 2-ethyl-1,4-benzoquinone (7) $\left(\mathrm{CDCl}_{3}\right.$, TMS, $400.13 \mathrm{MHz}$ for ${ }^{1} \mathrm{H}-\mathrm{NMR}$ and $100.61 \mathrm{MHz}$ for $\left.{ }^{13} \mathrm{C}-\mathrm{NMR}\right)$.

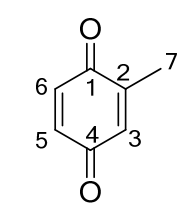

6

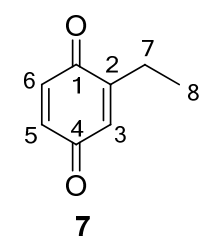

\begin{tabular}{ccc|cc}
\hline $\mathrm{C}$ & $\boldsymbol{\delta}_{\mathbf{H}}$ & $\boldsymbol{\delta}_{\mathbf{C}}{ }^{a}$ & $\boldsymbol{\delta}_{\mathbf{H}}$ & $\boldsymbol{\delta}_{\mathbf{C}}{ }^{b}$ \\
\hline 1 & - & n.d. $^{c}(\mathrm{C})$ & - & $187.5(\mathrm{C})$ \\
2 & - & n.d. ${ }^{c}(\mathrm{C})$ & - & $150.9(\mathrm{C})$ \\
3 & $6.62(1 \mathrm{H}, \mathrm{m})$ & $133.4(\mathrm{CH})$ & $6.57(1 \mathrm{H}, \mathrm{m})$ & $131.7(\mathrm{CH})$ \\
4 & - & n.d. $^{c}(\mathrm{C})$ & - & $187.9(\mathrm{C})$ \\
& $6.71\left(1 \mathrm{H}, \mathrm{dd},{ }^{3} J=10 \mathrm{~Hz} ;\right.$ & $136.5(\mathrm{CH})$ & $6.71\left(1 \mathrm{H}, \mathrm{dd},{ }^{3} J=10 \mathrm{~Hz} ;\right.$ & $136.3(\mathrm{CH})$ \\
& $\left.{ }^{4} J=2.25 \mathrm{~Hz}\right)$ & $\left.{ }^{4} \mathrm{~J}=2.25 \mathrm{~Hz}\right)$ & $136.8(\mathrm{CH})$ \\
6 & $6.77\left(1 \mathrm{H}, \mathrm{d},{ }^{3} J=10 \mathrm{~Hz}\right)$ & $136.6(\mathrm{CH})$ & $6.77\left(1 \mathrm{H}, \mathrm{d},{ }^{3} J=10 \mathrm{~Hz}\right)$ & $22.1\left(\mathrm{CH}_{2}\right)$ \\
7 & $2.07\left(3 \mathrm{H}, \mathrm{d},{ }^{4} J=1,5 \mathrm{~Hz}\right)$ & $15.8\left(\mathrm{CH}_{3}\right)$ & $2.47\left(2 \mathrm{H}, \mathrm{qd},{ }^{3} J=7.5 \mathrm{~Hz} ;{ }^{4} J=1.5 \mathrm{~Hz}\right)$ & $11.6\left(\mathrm{CH}_{3}\right)$ \\
\hline
\end{tabular}

${ }^{a}$ The results from ${ }^{13} \mathrm{C}$-NMR (fully decoupled, DEPT-90 and DEPT-135); ${ }^{b}$ The results from ${ }^{13} \mathrm{C}$-NMR (fully decoupled, DEPT-90 and DEPT-135), 2D NMR $g \operatorname{COSY}\left({ }^{1} \mathrm{H}-{ }^{1} \mathrm{H}\right)$ and $g \mathrm{HSQC}\left({ }^{1} \mathrm{H}_{-}{ }^{13} \mathrm{C}{ }^{1} \mathrm{~J}\right)$ experiments; ${ }^{c}$ not detected due to low abundance. 
The 1,4-hydroquinones 14-17 were detected in low abundance and identified by mass spectrometry using the peaks at $\mathrm{m} / \mathrm{z} 77$ and 91, which are typical of alkyl-substituted phenyl derivatives. Additionally, their intense molecular ions possessed two additional mass units when compared with the other corresponding major benzoquinones present in the same exudate (Figure 4). Some 1,4-hydroquinones are also reported for other gonyleptid species alongside their respective benzoquinones [3].

Figure 4. Benzoquinones and corresponding hydroquinones found in gonyleptid exudates.<smiles>CC1=C(C)C(=O)C=CC1=O</smiles><smiles>Cc1c(O)ccc(O)c1C</smiles><smiles>CCC1=CC(=O)C=CC1=O</smiles><smiles>CCc1cc(O)ccc1O</smiles>

Bourguyia trochanteralis Liogonyleptoides tetracanthus Mischonyx cuspidatus

Chavesincola inexpectabilis Pachylus paessleri<smiles>CCC1=C(C)C(=O)C=CC1=O</smiles>

Discocyrtus oliverioi Liogonyleptes tetracanthus

The exudate of Mi. cuspidatus has already been studied [3] and the composition was reported to be benzoquinone 9 (46.8\%) and its respective hydroquinone 15 (41.5\%). In the specimens we studied, the exudate did contain benzoquinone 9, but only $0.9 \%$ of 15 was found. The exudate of Pa. paessleri has also been previously studied [14], and the reported composition was similar to ours, except for the presence of the ketone $1(0.1 \%)$ and the hydroquinone $15(1.1 \%)$, reported here for the first time.

\subsubsection{Phenols Identification}

Phenol derivatives were detected in Me. longipes, Mp. variabilis and Pr. striatus. The exudates of Pr. striatus were clean enough to be analysed by mass spectrometry and NMR spectroscopy. The mass fragmentation of $\mathbf{1 8}$ and $\mathbf{2 0}$ revealed intense molecular ions at $m / z 122$ and 136 and fragments at $m / z 77$ and 91, which are typical of substituted aromatic rings (Figure 5).

Figure 5. Mass spectra of the alkyl phenols $\mathbf{1 8}$ and $\mathbf{2 0}$ from Progonyleptoidellus striatus.

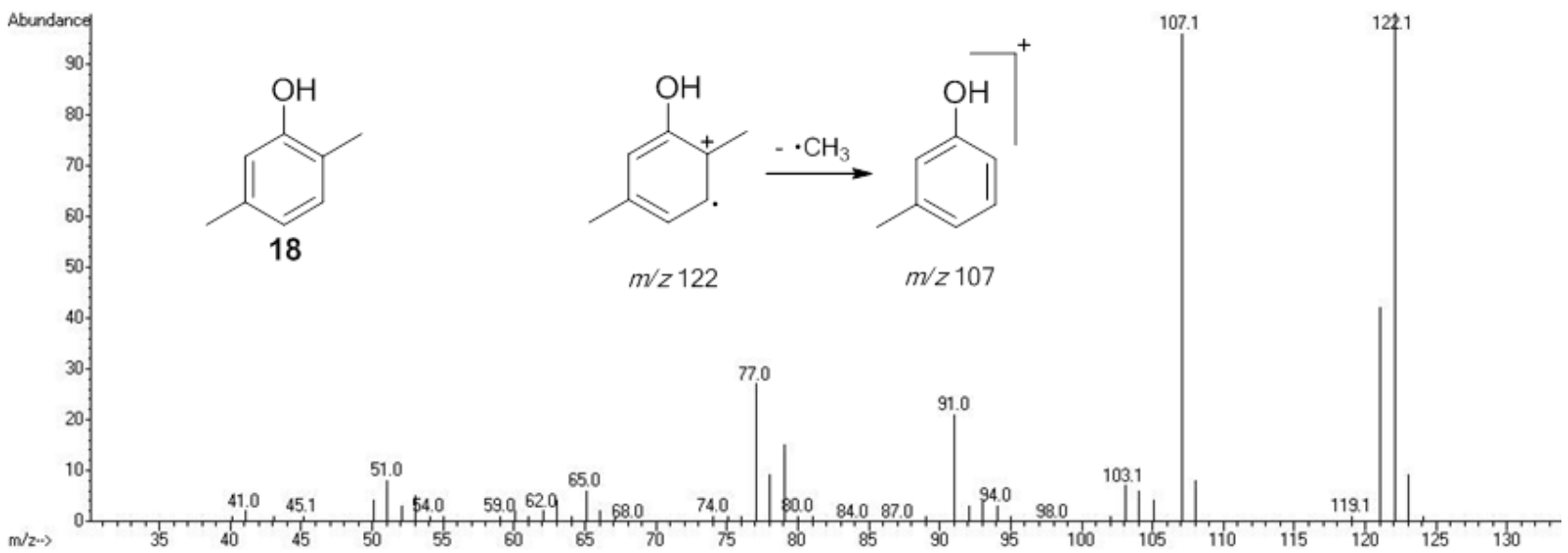


Figure 5. Cont.

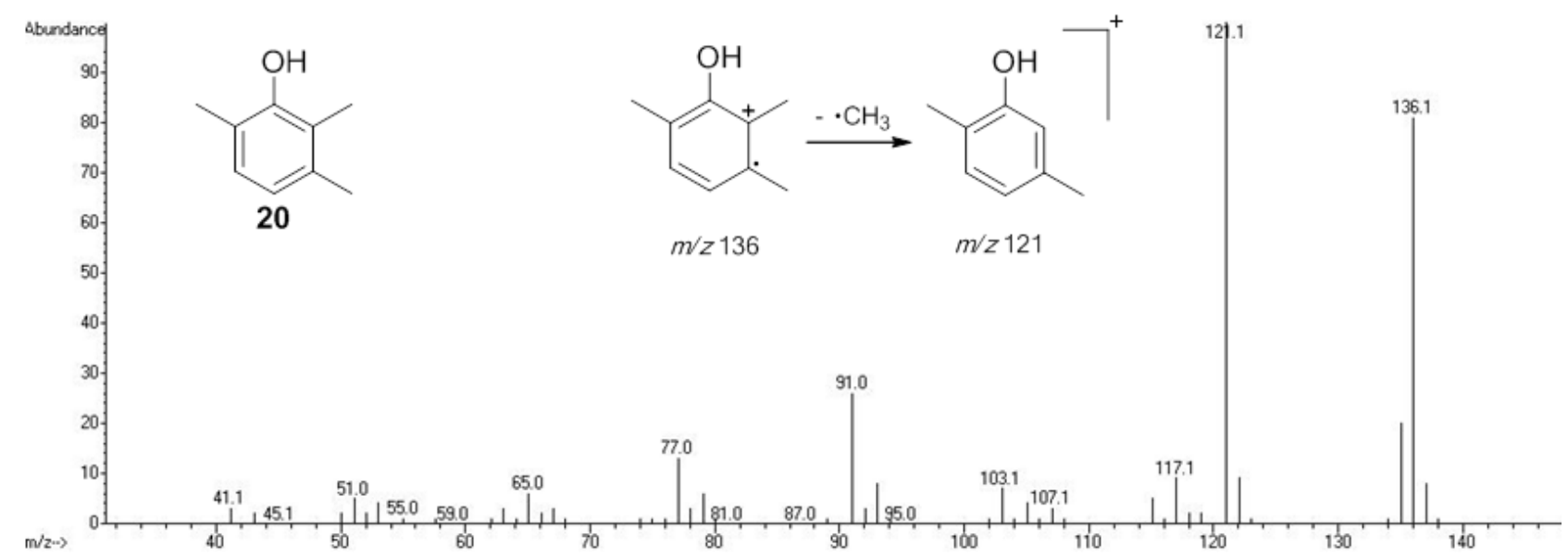

The NMR analysis of Pr. striatus revealed the expected methyl substituents and the substitution pattern of 18 (Figure 6a, Table 3). However, the structure of $\mathbf{2 0}$ could either be 2,3,6-trimethylphenol or 2,3,4-trimethylphenol. Differential Nuclear Overhauser Effect (NOE) experiments irradiating the aromatic hydrogens at 6.66 and 6.86 ppm enhanced the neighbouring methyl signals $8 \mathrm{~b}(\delta 2.24)$ and $9 \mathrm{~b}$ ( $\delta 2.22)$, respectively (Figure 6b, Table 3). Therefore, the structure of 2,3,6-trimethylphenol, in which the aromatic hydrogens are spatially next to both methyl groups, was assigned.

Figure 6. (a) ${ }^{1} \mathrm{H}-\mathrm{NMR}$ spectrum (499.89 $\mathrm{MHz}, \mathrm{CDCl}_{3}, \mathrm{TMS}$ ) of the harvestman Progonyleptoidellus striatus exudate containing phenols $\mathbf{1 8}$ and $\mathbf{2 0}$ as major components; (b) Differential NOE NMR experiments of Pr. striatus exudate.

(a)
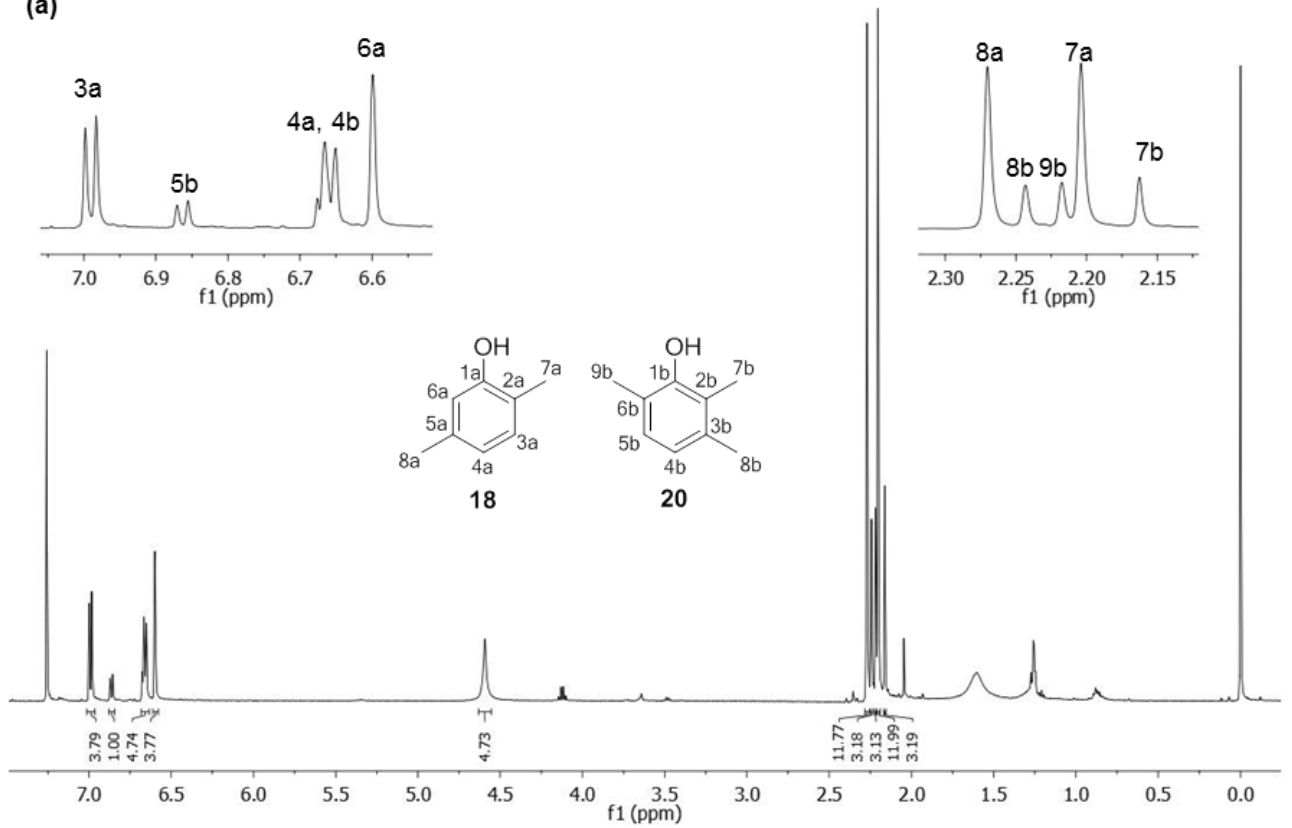
Figure 6. Cont.

(b)

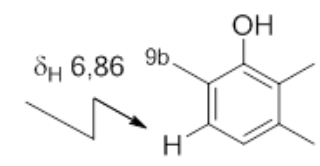

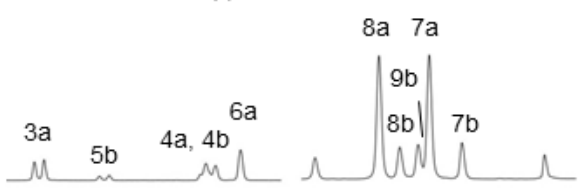

$0,62 \%$

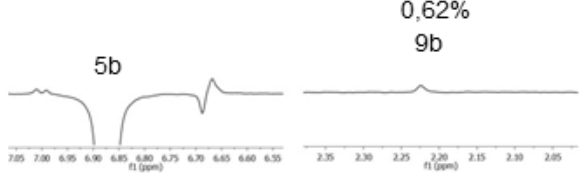

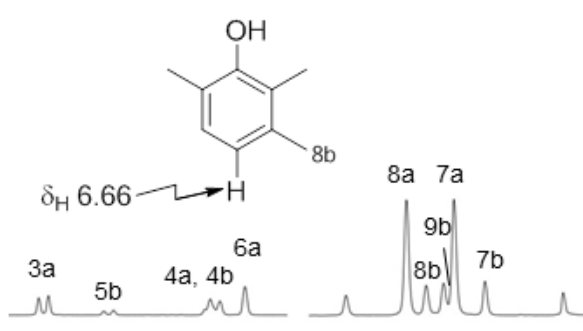

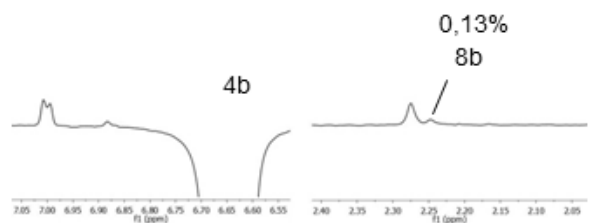

Table 3. NMR assignments of 2,5-dimethylphenol (18) and 2,3,6-trimethylphenol (20) $\left(\mathrm{CDCl}_{3}\right.$, TMS, $499.89 \mathrm{MHz}$ for ${ }^{1} \mathrm{H}-\mathrm{NMR}$ and $125.71 \mathrm{MHz}$ for $\left.{ }^{13} \mathrm{C}-\mathrm{NMR}\right)$.<smiles>Cc1ccc(C)c(O)c1</smiles>

18

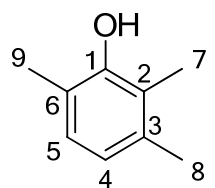

20

\begin{tabular}{ccc|cc}
\hline $\mathbf{X}$ & $\boldsymbol{\delta}_{\mathrm{H}}$ & $\boldsymbol{\delta}_{\mathbf{X}}{ }^{\alpha}$ & $\boldsymbol{\delta}_{\mathrm{H}}$ & $\boldsymbol{\delta}_{\mathbf{X}}{ }^{\alpha}$ \\
\hline 1 & - & $153.8(\mathrm{C})$ & - & $152.1(\mathrm{C})$ \\
2 & - & $120.6(\mathrm{C})$ & - & n.d. $^{b}$ \\
3 & $6.99\left(1 \mathrm{H}, \mathrm{d}^{3}{ }^{3} J=7.6 \mathrm{~Hz}\right)$ & $131.0(\mathrm{CH})$ & - & n.d. $^{b}$ \\
4 & $6.66\left(1 \mathrm{H}, \mathrm{d},{ }^{3} J=7.6 \mathrm{~Hz}\right)$ & $121.6(\mathrm{CH})$ & $6.66\left(1 \mathrm{H}, \mathrm{d}^{3} J=7.6 \mathrm{~Hz}\right)$ & $121.9(\mathrm{CH})$ \\
5 & - & $137.3(\mathrm{C})$ & $6.86\left(1 \mathrm{H}, \mathrm{d},{ }^{3} J=7.6 \mathrm{~Hz}\right)$ & $127.6(\mathrm{CH})$ \\
6 & $6.60(1 \mathrm{H}, \mathrm{s})$ & $115.8(\mathrm{CH})$ & - & n.d. $^{b}$ \\
7 & $2.20(3 \mathrm{H}, \mathrm{s})$ & $15.5\left(\mathrm{CH}_{3}\right)$ & $2.16(3 \mathrm{H}, \mathrm{s})$ & $11.9\left(\mathrm{CH}_{3}\right)$ \\
8 & $2.27(3 \mathrm{H}, \mathrm{s})$ & $21.2\left(\mathrm{CH}_{3}\right)$ & $2.24(3 \mathrm{H}, \mathrm{s})$ & $20.2\left(\mathrm{CH}_{3}\right)$ \\
9 & - & - & $2.22(3 \mathrm{H}, \mathrm{s})$ & $16.1\left(\mathrm{CH}_{3}\right)$ \\
\hline
\end{tabular}

${ }^{a}$ The results from ${ }^{13} \mathrm{C}$-NMR (fully decoupled, DEPT-90 and DEPT-135); ${ }^{b}$ not detected due to the low abundance of this minor compound.

The mass spectrum of 2-methyl-4-phenol (21) has an intense fragment at $m / z 121$, corresponding to a methyl loss, which is typical from an ethyl substituent. This identity was confirmed by co-elution with the exudate of the harvestman Hoplobunus mexicanus (Stygnopsidae), which was fully characterised by NMR spectroscopy [10].

Within the gonyleptid family, the occurrence of additional phenol derivatives has already been reported for some species, including Pachyloidellys goliath [8], Daguerreia inermis (both Pachylinae) [3], Camarana flavipalpi [9] and Pseudopachylus longipes (both Tricommatinae) [3]. Alkyl phenols are also found in species belonging to other families, such as Cynorta astora (Cosmetidae), which produces 19 and 21 [6], and Hoplobunus mexicanus (Stygnopsidae), which produces 18 and 21 [10]. 
Benzoquinones 6 (from C. inexpectabilis and Ma. neptunus), 8 (from Mu. terrenus, Pa. paessleri and Mi. cuspidatus) and phenol 18 (from Ps. striatus and Mp. variabilis) were tested against representative pathogenic microorganisms: a Gram-positive bacterium (Bacillus pumilus), a Gram-negative bacterium (Pseudomonas aeruginosa) and yeasts (Candida albicans and Rhodotorula glutinis). The disc diffusion method was applied to obtain the average inhibitory concentrations (data not shown), which were further evaluated in microtiter plates; MIC values are reported in Table 4 (see plates pictured in the Supporting Information).

Table 4. Minimal inhibitory concentration values (MIC) for harvestman scent gland components.

\begin{tabular}{lccc}
\hline & \multicolumn{3}{c}{ MIC $(\boldsymbol{\mu g} / \mathbf{m L})$} \\
Microorganism & $<125$ & $<125$ & 250 \\
\hline Bacillus pumilus & $<125$ & $<125$ & 1000 \\
Pseudomonas aeruginosa & 125 & $<82.5$ & $>500$ \\
Candida albicans & $<82.5$ & $<82.5$ & $<82.5$ \\
Rhodotorula glutinis & & $\mathbf{6}$ & \\
\hline
\end{tabular}

Phenol 18 has lower biological activity than benzoquinones $\mathbf{6}$ and $\mathbf{8}$ against all tested microorganisms, except for $R$. glutinis. The biological activities of benzoquinones $\mathbf{6}$ and $\mathbf{8}$ were very similar against all tested microorganisms, except for $C$. albicans. The biological activity of the benzoquinones has been assigned to the electrophilic character of the conjugated double bond [27].

Benzoquinone 6 and its corresponding hydroquinone were tested together with other benzoquinone derivatives against Bacillus subtilis, Micrococcus luteus, and C. albicans, showing moderated antimicrobial activity [28]. Ruther and coworkers [23] also found $\mathbf{6}$ had antimicrobial activity against Escherichia coli, Saccharomyces cerevisiae, and the entomopathogenic fungi Metarhizium anisopliae and Beauveria brongniartii.

The antimicrobial activity of phenolic compounds was attributed to membrane permeabilisation, followed by cellular damage [29,30]. A set alkyl phenols were tested against oral bacteria revealing that the ortho-substituents on the phenolic groups decreased the biological activity [31]. In fact, $o$-phenol 18 displayed higher MIC values (Table 4). The dramatic MIC difference displayed by 18 against Gram-positive and Gram-negative bacteria is caused by the lipophilicity of this compound. Therefore, Gram-negative bacteria such as $P$. aeruginosa, have up to $25 \%$ of lipidic content and can retain the liposoluble phenols, while Gram-positive species, such as B. pumilus have $0 \%$ to $3 \%$, therefore allowing the phenol to cause cellular membrane damage [31].

\subsection{Biosynthetic Study of Magnispina neptunus Benzoquinone}

In a previous report, we described the polyketide pathway for a harvestman vinyl ketone [24], in which the polyketide chain was composed of $\mathrm{Pr}+\mathrm{Ac}+\mathrm{Pr}$ units. To investigate whether this biosynthetic pathway was also present in the quinone producing harvestmen, we selected Ma. neptunus as a model species. We added $\left[1-{ }^{13} \mathrm{C}\right]$ acetate and $\left[4-{ }^{13} \mathrm{C}\right]$ methylmalonate as precursors incorporated into the diet 
of the individuals, and the labelling of 7 was monitored by ${ }^{13} \mathrm{C}-\mathrm{NMR}$ spectroscopy. The observed enrichment was typical of an aromatic polyketide pathway [32], yielding ${ }^{13} \mathrm{C}$ labelling at $\mathrm{C}-2, \mathrm{C}-4$, and C-6 of 7, which are alternating carbons on the benzoquinone ring (Figure 7, Scheme 1).

Figure 7. ${ }^{13} \mathrm{C}$-NMR spectra $\left(\mathrm{CDCl}_{3}\right)$ of 2-ethyl-1,4-benzoquinone (7) after the feeding experiment with Magnispina neptunus individuals. Black arrow: control signal; blue arrow: enriched positions. Balls on the structures indicate enriched positions.

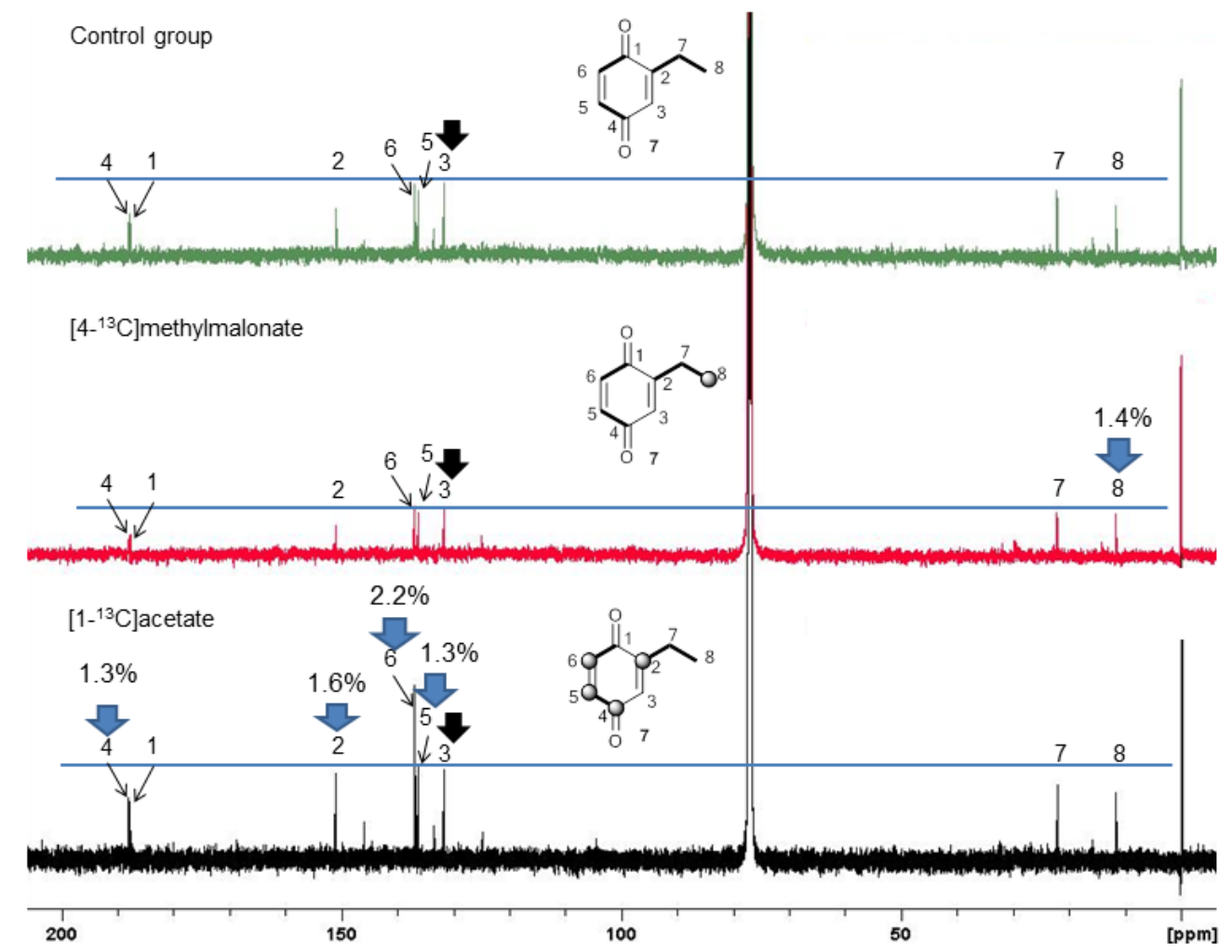

Feeding the individuals $\left[4-{ }^{13} \mathrm{C}\right]$ methylmalonate enriched 7 only at C-8 (Figure 7), which is consistent with the incorporation of a propionyl-CoA starter unit (Scheme 1). This labelling pattern also indicates that the alternative catabolism of propionate to acetate via 3-hydroxypropionate [33] does not occur in Ma. neptunus because the positions corresponding to acetate units were not enriched. The same was effect was observed for the vinyl ketone pathway in the harvestman Iporangaia pustulosa [24].

$\left[1-{ }^{13} \mathrm{C}\right]$ acetate incorporation enriched C-2, C-4 and C-6 of 7. Positions C-4 and C-6 are clearly labelled due to malonate incorporation. The third extender unit loses its labelled carbon, leaving only the non-labelled carbon at C-3. The unexpected enrichment at C-2 is consistent with the incorporation of a propionate unit and the conversion of $\left[1-{ }^{13} \mathrm{C}\right]$ acetate into $\left[1-{ }^{13} \mathrm{C}\right]$ propionate via succinyl-CoA with a methylmalonyl-CoA mutase, as reported for the harvestman I. pustulosa [24]. However, the $\mathrm{C}_{3}$ label scrambling observed in I. pustulosa was not present in biosynthetic pathway of 7 for Ma. neptunus, suggesting a simpler propionate metabolism for this species. 
Scheme 1. (a) Biosynthetic route for 7 in the harvestman Magnispina neptunus; (b) Labelling pattern of 7 after feeding a labelled precursor to Ma. neptunus individuals. Black balls indicate the enriched positions, and the red ball indicates unexpected enrichment.

(a) 3<smiles>COS(=O)(=O)C(=O)CC(=O)[O-]</smiles>

1 CoA<smiles>CC#CCCC(=O)[SH](C)(C)(C)C</smiles><smiles>CCC(=O)CC(=O)CC(=O)CC(=O)C1CCCCC1</smiles>

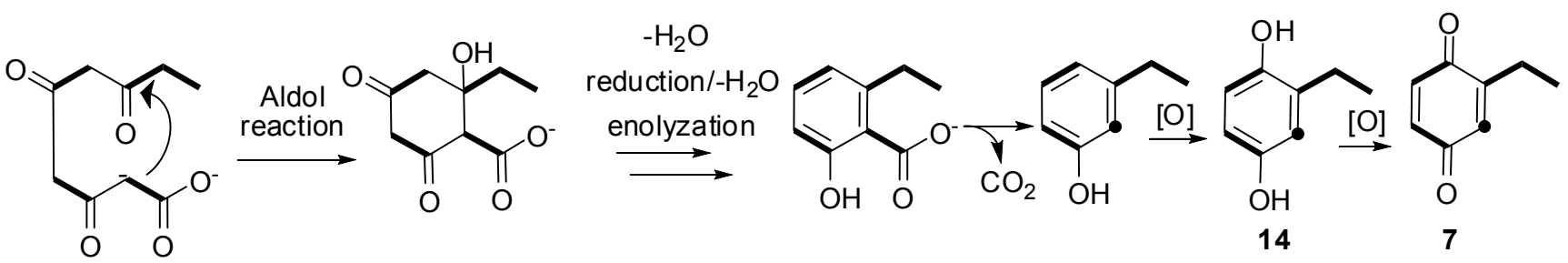

(b)
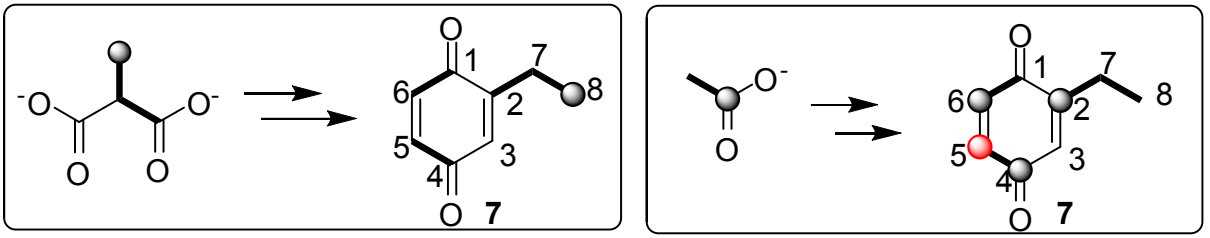

The labelling at $\mathrm{C}-5$ by $\left[1-{ }^{13} \mathrm{C}\right]$ acetate was also unexpected (Scheme 1 ) because it corresponds to the $\mathrm{C}-2$ of the incorporated malonate unit. The enrichments at C-4 and C-5, which belong to the same acetate unit, are identical (1.3\%), excluding the possibility of a measurement error. On the other hand, C-2 and C-6 belong to two $\mathrm{C}_{2}$ independent units with $1.6 \%$ and $2.2 \%$ of enrichment, respectively. Considering that the three $\mathrm{C}_{2}$ extender units are malonate, their metabolism should be similar. Therefore, this scrambled labelling suggests that the malonate biosynthesis has more than one route to produce and incorporate this unit onto a hypothetic domain of the PKS. Analogous results were reported for the I. pustulosa vinyl ketone biosynthesis [24].

Benzoquinone $\mathbf{6}$ is the minor constituent of the Ma. neptunus exudate and was not detected in the NMR spectra because it had a very low relative abundance. However, its biosynthetic pathway may be similar to 7, with an acetate starter unit rather than a propionate. The same rationale may be applied to the biosynthesis of the benzoquinones detected in the nine species described in this study, in which changes to the starter and extender units' assembly provide a different polyketide chain, and therefore generate a set of benzoquinones with different substitution patterns (Scheme 2).

Meinwald and coworkers reported that both aromatic amino acids and carboxylic acids are precursors for unsubstituted 1,4-benzoquinones in the beetle Eleodes longicollis [34]. However, the incorporation data for the substituted benzoquinones, such as $\mathbf{6}$ and $\mathbf{7}$, are better accommodated in a polyketide pathway due to the exclusive incorporation of acetate and propionate as starter and extender units, respectively [34]. Sun and Toia studied the biosynthesis of 2,4-dihydroxyacetophenone in the ant Rhytidoponera chalybaea revealing the polyketide origin of this aromatic compound in insects [35].

The proposed benzoquinone biosynthetic routes in harvestmen occur via carbonyl enolysation of the cyclised polyketide chain, followed by a decarboxylation (Scheme 1), which is the final step for phenols 18-21 from Me. longipes, Mp. variabilis and Pr. striatus (Scheme 2). Eisner and co-workers reported that benzoquinone 9 and phenol 21 from Zygopachylus albimarginis (Manaosbiidae) [6] had the same biosynthetic origin for both components. The production of benzoquinones, hydroquinones 
and phenols by the forked fungus beetle Bolitotherus cornutus also suggests that the alkyl benzoquinones and alkyl phenols might share a similar biosynthetic origin [36].

Scheme 2. Proposed biosynthetic routes for harvestman benzoquinones and phenols. Black balls indicate a broken acetate unit caused by benzoquinone decarboxylation.

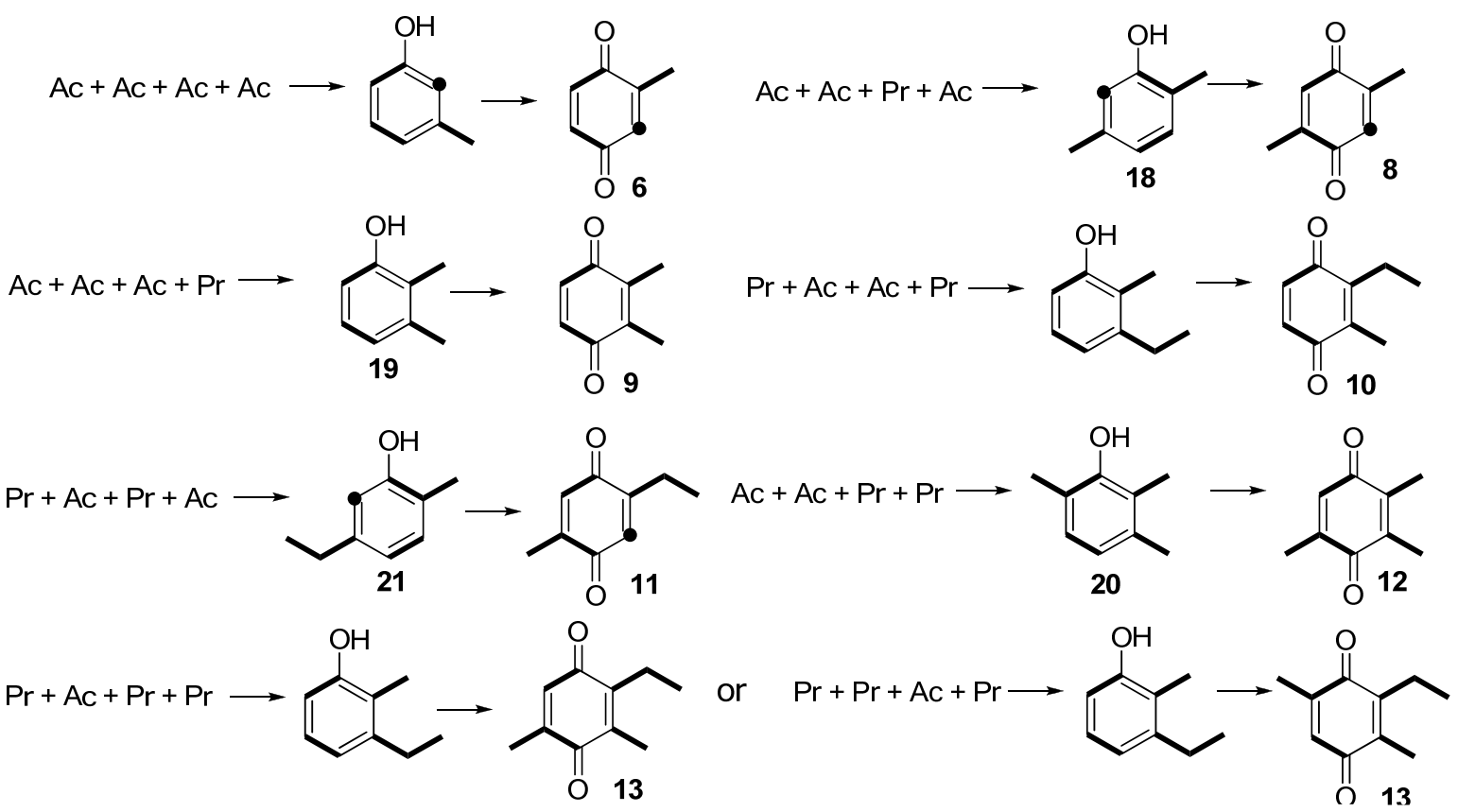

In five of the 12 studied harvestman exudates, the benzoquinone and its corresponding 1,4-hydroquinone occur together (Figure 4). This feature provides additional evidence for the proposed biosynthetic route of phenol $p$-oxidation to provide 1,4-benzoquinones. A classic example of this mechanism is the bombardier beetle (Carabidae), which enzymatically oxidises 1,4-hydroquinones with a catalase producing 1,4-benzoquinones, water and heat [17,18,37]. Beetles of the family Tenebrionidae also produce 1,4-benzoquinones from 1,4-hydroquinone oxidation [15,19,20].

The alkyl and methoxybenzoquinones are also often components of millipede defensive secretions alongside their corresponding hydroquinones [38-41]. Some millipede species in the families Spirostreptidae and Harpagophoridae secrete benzoquinones 6 and 7, the hydroquinone 15 and several methoxy substituted benzo- and hydroquinones. According to our hypothesis, the putative biosynthetic route for these compounds is the $p$-oxidation of hydroquinones; however, there have been no labelling experiments using millipedes [39].

Based on these results, as well as on our previous report [24], it can be inferred that harvestmen catabolise propionate to form acetate via succinyl-CoA, followed by the TCA cycle, while insects oxidise the propionate to form acetate via 3-hydroxypropionate [33,42]. The biosynthetic pathway observed in harvestmen most likely relies on the participation of a methylmalonyl-CoA mutase, which is an enzyme exclusive to non-insect arthropods [42-45]. This feature appears to indicate a key metabolic difference between insects and other arthropods, such as arachnids. The labelling pattern found in the I. pustulosa biosynthetic study revealed that this species possesses a complex propionate metabolism, in which the labelling scrambling indicates different loadings of $\mathrm{C}_{3}$ starter and extender 
units [24]. The scrambling was also present in Ma. neptunus, but it was observed only for $\mathrm{C}_{2}$ extender unit incorporation.

\section{Experimental}

\subsection{Chemical Profile of Harvestman Exudates}

\subsubsection{General Methods}

The NMR spectra were acquired with either an $11 \mathrm{~T}$ Varian Inova instrument, operating at 499.88 MHz for ${ }^{1} \mathrm{H}-\mathrm{NMR}$ and $125.71 \mathrm{MHz}$ for ${ }^{13} \mathrm{C}-\mathrm{NMR}$, or a $5.87 \mathrm{~T}$ Bruker Avance DPX, at 250.13 MHz for ${ }^{1} \mathrm{H}-\mathrm{NMR}$ and $62.89 \mathrm{MHz}$ for ${ }^{13} \mathrm{C}-\mathrm{NMR}$. The solvent was $\mathrm{CDCl}_{3}$ and tetramethylsylane (TMS) was an internal reference $(0.0 \mathrm{ppm})$. The chemical shifts $(\delta)$ are reported in ppm and coupling constants $J$ are reported in Hz. The GC-MS analyses were performed using an Agilent 6890-5973 system with a DB-5 fused silica capillary column $(30 \mathrm{~m} \times 0.25 \mathrm{~mm} \times 0.25 \mu \mathrm{m})$. The EIMS were recorded at $70 \mathrm{eV}$ using $3.54 \mathrm{scans} \cdot \mathrm{s}^{-1}$ from $\mathrm{m} / \mathrm{z} 40$ to 400 . The oven temperature ranged from 50 to $200{ }^{\circ} \mathrm{C}$ at $10{ }^{\circ} \mathrm{C} \cdot \mathrm{min}^{-1}$ and subsequently to $290{ }^{\circ} \mathrm{C}$ at $16^{\circ} \mathrm{C} \cdot \mathrm{min}^{-1}$. The natural samples were injected in splitless mode, while the synthetic samples were injected in split 1:10 mode. The injector temperature was $250{ }^{\circ} \mathrm{C}$ and the detector was maintained at $280{ }^{\circ} \mathrm{C}$; helium was used as the carrier gas. The retention index (RI) [46] was determined using splitless injection mode and temperatures ranging from 50 to $290{ }^{\circ} \mathrm{C}$ at a rate of $4{ }^{\circ} \mathrm{C} \cdot \mathrm{min}^{-1}$ and $7.62 \mathrm{psi}$; an alkane standard solution $\mathrm{C}_{8}-\mathrm{C}_{20}$ (Fluka) was injected using the same program. The HREIMS were acquired using a Waters GCT premier at $20 \mathrm{scans}^{-1} \mathrm{~s}^{-1}$, at a resolution of 7,000 FWHM, with sub-5 ppm RMS with an internal lock mass correction and electron impact (EI) at $70 \mathrm{eV}$. The Agilent 7683 operated with oven temperature ranging from 50 to $250{ }^{\circ} \mathrm{C}$ at $10{ }^{\circ} \mathrm{C} \cdot \mathrm{min}^{-1}$ and HP5-MS column with $30 \mathrm{~m} \times 0.25 \mathrm{~mm} \times 0.25 \mu \mathrm{m}$ for $\mathrm{GC}$ analysis. The injection volume was $1 \mu \mathrm{L}$ in splitless mode. The injector temperature was $270{ }^{\circ} \mathrm{C}$ and the detector was kept at $250{ }^{\circ} \mathrm{C}$ while using helium as the carrier gas.

\subsubsection{Collection of Individuals}

The individuals were collected in different places, most of them in the Atlantic Forest in southeastern (SE) Brazil (Table 5) during the wet and warm season (October to March), when the individuals of many gonyleptid species are more active. Individuals of the studied species were taken to the laboratory and kept alive in plastic vials containing a piece of wet cotton to maintain moisture. The scent gland exudates were collected by pressing the gland openings with cotton wool cleaned with bidistilled EtOAc. The liquid absorbed in the cotton wool was washed off with $\mathrm{CDCl}_{3}(2 \mathrm{~mL})$ for NMR analyses before being eluted with EtOAc $(2 \mathrm{~mL})$ for GC-MS analyses. All solvents were of high analytical grade and were doubly distilled before use. 
Table 5. Identity of the gonyleptid species used in this study. The column "Locality" indicates the places where the individuals were collected in the field and the column "Number of individuals" indicates the sample size used in the chemical analyses.

\begin{tabular}{|c|c|c|}
\hline Species & Locality & Number of individuals \\
\hline \multicolumn{3}{|l|}{ BOURGOUYINAE } \\
\hline Bourguyia trochanteralis & Cananéia, São Paulo, SE Brazil & 22 \\
\hline \multicolumn{3}{|l|}{ CAELOPYGINAE } \\
\hline Metarthrodes longipes & Ubatuba, São Paulo, SE Brazil & 3 \\
\hline \multicolumn{3}{|l|}{ GONYLEPTINAE } \\
\hline Liogonyleptoides tetracanthus & Linhares, Espírito Santo, SE Brazil & 9 \\
\hline Mischonyx cuspidatus & Campinas, São Paulo, SE Brazil & 29 \\
\hline \multicolumn{3}{|l|}{ HERNANDARIINAE } \\
\hline Multumbo terrenus & Teresópolis, Rio de Janeiro, SE Brazil & 30 \\
\hline \multicolumn{3}{|l|}{ HETEROPACHYLINAE } \\
\hline Chavesincola inexpectabilis & Santa Tereza, Espírito Santo, SE Brazil & 31 \\
\hline Magnispina neptunus & Arraial D’Ajuda, Bahia, NE Brazil & 20 \\
\hline \multicolumn{3}{|l|}{ PACHYLINAE } \\
\hline Discocyrtus oliverioi & Campinas, São Paulo, SE Brazil & 11 \\
\hline Pachylus paessleri & San Carlos de Apoquindo, Santiago, Chile & 24 \\
\hline \multicolumn{3}{|l|}{ PACHYLOSPELEINAE } \\
\hline Pachylospeleus strinati & Iporanga, São Paulo, SE Brazil & 34 \\
\hline \multicolumn{3}{|l|}{ PROGONYLEPTOIDELINAE } \\
\hline Mitopernoides variabilis & Ubatuba, São Paulo, SE Brazil & 9 \\
\hline Progonyleptoidellus striatus & Santo André, São Paulo, SE Brazil & 10 \\
\hline
\end{tabular}

\subsection{Antimicrobial Activity}

Bacillus pumillus (LaBioSin collection) and Pseudomonas aeruginosa (CCT 1987) were cultured in Nutrient Broth (NB) (peptone $10 \mathrm{~g}$, glucose $40 \mathrm{~g}$ and agar $15 \mathrm{~g}$, and the volume completed to $1 \mathrm{~L}$ with distilled water). Candida albicans (CCT 0776) and Rhodotorula glutinis (CCT 0783) were cultured in yeast-malt extract (YM) Merck (yeast extract $3 \mathrm{~g}$, malt-extract $3 \mathrm{~g}$, peptone $5 \mathrm{~g}$, glucose $10 \mathrm{~g}$ and agar $20 \mathrm{~g}$, and the volume completed to $1 \mathrm{~L}$ with distilled water). The microorganisms were cultured in $10 \mathrm{~mL}$ of the medium for $24 \mathrm{~h}$ before the MIC experiment. Aqueous microorganism suspensions $(100 \mu \mathrm{L}$, $1.5 \cdot \times 10^{7}$ cells $\cdot \mathrm{mL}^{-1}$ ) were added to the wells of a 96 titer plate. The bioactive compounds $\mathbf{6}, \mathbf{8}$ and 18 $(100 \mu \mathrm{L})$ in final concentrations of $1,000,500,250$ and $125 \mu \mathrm{g} \cdot \mathrm{mL}^{-1}$ for bacteria and 500, 250, 125 and $82.5 \mu \mathrm{g} \cdot \mathrm{mL}^{-1}$ for yeast, diluted in $\mathrm{H}_{2} \mathrm{O} / \mathrm{DMSO}$ 95:5 $(v / v)$ were added in the wells. Positive controls were prepared by substituting the test compounds by either chloramphenicol $\left(4 \mathrm{mg} \cdot \mathrm{mL}^{-1}\right)$ for bacteria and ciclopiroxolamine $\left(10 \mathrm{mg} \cdot \mathrm{mL}^{-1}\right)$ for the yeast. Negative controls were prepared using only the aqueous DMSO plus inoculum. The plates were incubated at $30{ }^{\circ} \mathrm{C}$ for $24 \mathrm{~h}$. Aliquots of $20 \mu \mathrm{L}$ of aqueous MTT $\left(1 \mathrm{mg} \cdot \mathrm{mL}^{-1}\right)$ were added to the wells, and the reduction of the terazolium salt (yellow) to formazan (blue) by living cells was observed within $1 \mathrm{~h}$. All of the tests were run in triplicates. 


\subsection{Biosynthetic Study of Magnispina neptunus}

The individuals used in the biosynthetic study were collected at Arraial D'Ajuda, state of Bahia, northeastern Brazil. Before beginning the experiment, a dorso-ventral pressure was applied to all of the individuals to empty their gland sacs. The individuals were divided into two groups and fed with canned dog food containing $5 \% \mathrm{w} / \mathrm{w}$ of the labelled precursors: $\left[1-{ }^{13} \mathrm{C}\right]$ sodium acetate (Cambridge Isotope Laboratories, CIL, Tewksbury, MA, USA) $(\mathrm{n}=40$ individuals $)$ and $\left[4-{ }^{13} \mathrm{C}\right]$ sodium methylmalonate (for synthetic procedure see [17]) $(\mathrm{n}=33$ individuals). The control group was the exudate extracted before initiating each experiment $(n=68$ individuals). The experiment was set up over a period of 60 days, and the food was renewed every $48 \mathrm{~h}$. The exudates were collected with dewaxed cotton wool and extracted from the cotton wool with $\mathrm{CDCl}_{3} .{ }^{13} \mathrm{C}-\mathrm{NMR}$ spectra of 7 were acquired with a Bruker Avance III 11 tesla operating at $125.75 \mathrm{MHz}, 25^{\circ} \mathrm{C}$, acquisition time $1.1 \mathrm{~s}, 30^{\circ}$ pulse, and approximately 40,000 scans, using equal scan numbers for samples within the same experiment (sample and control) $[47,48]$.

\section{Conclusions}

The chemical characterisation of the 12 harvestman exudates provides important information related to the chemotaxonomy of the gonyleptid harvestmen. For three species studied here (L. tetracanthus, Me. longipes and Mp. variabilis), there was no previous chemical characterisation in the literature. The data for these three species, which were not included in the recent phylogeny of the Gonyleptidae, support the notion that the production of benzoquinones is plesiomorphic in the family [49]. Additionally, the production of alkyl-phenols evolved several times independently from the ancestral states of production of benzoquinones and vinyl ketones [49]. These frequent evolutionary transitions agree with the proposed biosynthetic route for benzoquinones, phenols and ketones, all of which begin from acetate and propionate units in a common polyketide pathway. Specifically, our studies with I. pustulosa [24] and Ma. neptunus indicate that these phylogenetically distant species partially share the biosynthetic pathway for vinyl ketones and benzoquinones, respectively (Scheme 3). Additionally, the scrambled labelling at specific positions of the polyketide chain also indicates that the biosynthetic routes are complex, offering several opportunities for the diversification of the molecules produced within both species.

Scheme 3. Biosynthetic pathway for vinyl ketone and benzoquinone in harvestmen.

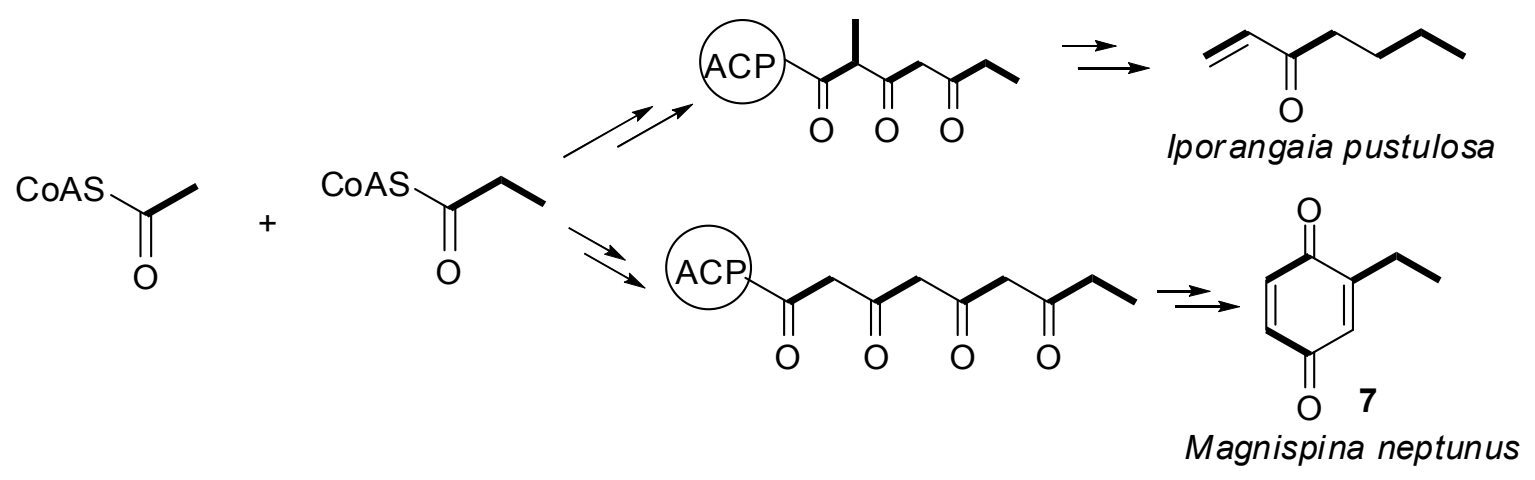


Most species that produce benzoquinones live on the ground, taking shelter under rocks or rotten logs [49]. In these types of habitats, individuals are likely to be in direct contact with many pathogenic microorganisms [50]. However, most species living on low and high vegetation produce phenols and ketones as the main constituents of their defensive exudates [24]. The results from our experiments concerning antimicrobial activity revealed that the minimal inhibitory concentration values for benzoquinones are consistently lower than for phenols, suggesting that the benzoquinones are more effective at deterring microorganisms. Therefore, the diversification of the chemical compounds in the defensive exudates of gonyleptid harvestmen may be at least partially explained by the differences in habitat-related uses among the species of different subfamilies.

\section{Supplementary Materials}

Supplementary materials can be accessed at: http://www.mdpi.com/1420-3049/18/9/11429/s1.

\section{Acknowledgments}

We acknowledge D. Caetano, B. Buzatto, R. Pinto-da-Rocha, C. Bragagnollo, R. Werneck, G. S. Requena, T. M. Nazareth and A. L. Guil for helping to collect the individuals, and CNPq, Petrobrás, and Fundação de Amparo à Pesquisa do Estado de São Paulo (FAPESP-GM 08/06604-7) and FAPESP-VALE (AJM 10/51278-0) for financial support.

\section{Conflicts of Interest}

The authors declare no conflict of interest.

\section{References}

1. Machado, G.; Pinto-da-Rocha, R.; Giribet, G. What are Harvestmen. In Harvestmen: The Biology of Opiliones; Pinto-Da-Rocha, R., Machado, G., Giribet, G., Eds.; Harvard University Press: Cambridge, MA, USA, 2007.

2. Raspotnig, G. Scent gland chemistry and chemosystematics in harvestmen. Biol. Serbica 2012, 34, 5-18.

3. Hara, M.R.; Cavalheiro, A.J.; Gnaspini, P.; Santos, D.Y.A.C. A comparative analysis of the chemical nature of defensive secretions of Gonyleptidae (Arachnida: Opiliones: Laniatores). Biochem. Syst. Ecol. 2005, 33, 1210-1225.

4. Rocha, D.F.O.; Hamilton, K.; Gonçalves, C.C.S.; Machado, G.; Marsaioli, A.J. 6-Alkyl-3,4-dihydro-2H-pyrans: Chemical secretion compounds in neotropical harvestmen. J. Nat. Prod. 2011, 74, 658-663.

5. Wouters, F.C.; Rocha, D.F.O.; Gonçalves, C.C.S.; Machado, G.; Marsaioli, A.J. Additional vinyl ketones and their pyranyl ketones in gonyleptid harvestmen (Arachnida: Opiliones) suggest that the hetero-Diels-Alder reaction is widespread in this family. J. Nat. Prod. 2013, doi:10.1021/np4001569.

6. Eisner, T.; Jones, T.H.; Hicks, K.; Silberglied, R.E.; Meinwald, J. Quinones and phenols in the defensive secretions of neotropical opilionids. J. Chem. Ecol. 1977, 3, 321-329. 
7. Duffield, R.M.; Olubajo, O.; Wheeler, J.W.; Shear, W.A. Alkylphenols in the defensive secretion of the nearctic opilionid, Stygnomma spinifera (Arachnida: Opiliones). J. Chem. Ecol. 1981, 7, $445-452$.

8. Acosta, L.E.; Poretti, T.I.; Mascarelli, P.E. The defensive secretions of Pachyloidellus goliath (Opiliones, Laniatores, Gonyleptidae). Bonn. Zool. Beitr. 1993, 44, 19-31.

9. Machado, G.; Pomini, A.M. Chemical and behavioral defenses of the neotropical harvestman Camarana flavipalpi (Arachnida: Opiliones). Biochem. Syst. Ecol. 2008, 36, 369-376.

10. Pomini, A.M.; Machado, G.; Pinto-da-Rocha, R.; Macías-Ordóñez, R.; Marsaioli, A.J. Lines of defense in the harvestman Hoplobunus mexicanus (Arachnida: Opiliones): Aposematism, stridulation, thanatosis, and irritant chemicals. Biochem. Syst. Ecol. 2010, 38, 300-308.

11. Estable, C.; Ardao, M.I.; Brasil, N.P.; Fieser, L.F. Gonyleptidine. J. Am. Chem. Soc. 1955, 77, 4942.

12. Eisner, T.; Rossini, C.; Gonzalez, A.; Eisner, M. Chemical defense of an opilionid (Acanthopachylus aculeatus). J. Exp. Biol. 2004, 207, 1313-1321.

13. Machado, G.; Carrera, P.C.; Pomini, A.M.; Marsaioli, A.J. Chemical defense in harvestmen (Arachnida, Opiliones): Do benzoquinone secretions deter invertebrate and vertebrate predators? J. Chem. Ecol. 2005, 31, 2519-2539.

14. Föttinger, P.; Acosta, L.E.; Leis, H.; Raspotnig, G. Benzoquinone-rich exudates from the harvestman Pachylus paessleri (Opiliones: Gonyleptidae: Pachylinae). J. Arachnol. 2010, 38, 584-587.

15. Blum, M.S. Biosynthesis of arthropods exocrine compounds. Ann. Rev. Entomol. 1987, 32, 381-413.

16. Abraham, I.; Joshi, R.; Pardasani, P.; Pardasani, R.T. Recent advances in 1,4-benzoquinone chemistry. J. Braz. Chem. Soc. 2011, 22, 385-421.

17. Schildknecht, H.; Holoubek, K. Die bombardierkafer und ihre explosionschemie. Angew. Chem. 1961, 73, 1-7.

18. Eisner, T.; Jones, T.H.; Aneshansley, D.J.; Tschinkel, V.R.; Silberglied, R.E.; Meinwald, J. Chemistry of defensive secretions of bombardier beetles (Brachinini, Metriini, Ozaenini, Paussini). J. Insect Physiol. 1977, 23, 1383-1386.

19. Happ, G.M. Quinone and hydrocarbon production in the defensive glands of Eleodes longicollis and Tribolium castaneum (Coleoptera, Tenebrioidae). J. Insect Physiol. 1968, 14, 1821-1837.

20. Ikanl, R.; Cohen, E.; Shulov, A. Benzo- and hydroquinones in the defense secretions of Blaps sulcata and Blaps wiedemanni. J. Insect Physiol. 1970, 16, 2201-2206.

21. Eisner, T.; Rossini, C.; Eisner, M. Chemical defense of an earwig (Doru taeniatum). Chemoecology 2000, 10, 81-87.

22. Olagbemiro, T.O; Lajide, L.; Sani, K.M.; Staddon, B.W. 2-Hydroxy-5-methyl-1,4-benzoquinone from the salivary gland of the soldier termites Odontotermes magdalenae. Experientia 1988, 44, 1022-1024.

23. Ruther, J.; Podsiadlowski, L.; Hilker, M. Quinones in cockchafers: Additional function of a sex attractant as an antimicrobial agent. Chemoecology 2001, 11, 225-229.

24. Rocha, D.F.O.; Wouters, F.C.; Machado, G.; Marsaioli, A.J. Alternative sources of propionate and methylmalonate in the biosynthesis of a vinyl ketone in the defensive secretion of an arachnid. Sci. Reports 2013, submitted for publication. 
25. Pankewitz, F.; Hilker, M. Polyketides in insects: Ecological role of these widespread chemicals and evolutionary aspects of their biogenesis. Biol. Rev. 2008, 83, 209-226.

26. Gross, J.H. Mass Spectrometry-A Textbook, 2nd ed; Springer-Verlag: Heidelberg, Germany, 2011.

27. El-Najar, N.; Gali-Muhtasib, H.; Ketola, R.A.; Vuorela, P.; Urtti, A.; Vuorela, H. The chemical and biological activities of quinones: Overview and implications in analytical detection. Phytochem. Rev. 2011, 10, 353-370.

28. Cole, L.K.; Blum, M.S.; Roncadori, R.W. Antifungal properties of the insect alarm pheromones, citral, 2-heptanone, and 4-methyl-3-heptanone. Mycologia 1975, 67, 701-708.

29. Shapiro, S.; Guggenheim, B. The action of thymol on oral bacteria. Oral Microbiol. Immunol. 1995, 10, 241-246.

30. Tortora, G.J.; Funke, B.R.; Case, C.L. Microbiology: An Introduction, 10th ed.; Pearson Benjamin Cummings: San Francisco, CA, USA, 2010.

31. Greenberg, M.; Dodds, M.; Tian, M. Naturally occurring phenolic antibacterial compounds show effectiveness against oral bacteria by a quantitative structure-activity relationship study. J. Agric. Food Chem. 2008, 56, 11151-11156.

32. Morgan, E.D. Biosynthesis in Insects, Advanced ed.; RSC: Cambridge, UK, 2010.

33. Halarnkar, P.P.; Chambers, J.D.; Blomquist, G.J. Metabolism of propionate to acetate in nine insect species. Comp. Biochem. Physiol. 1986, 84, 469-472.

34. Meinwald, J.; Koch, K.F.; Rogers, J.E., Jr.; Eisner, T. Biosynthesis of arthropod secretions. III. Synthesis of simple p-benzoquinones in a beetle (Eleodes longicollis). J. Am. Chem. Soc. 1966, $88,1590-1592$.

35. Sun, C.M.; Toia, R.F. Biosynthetic studies on ant metabolites of Mellein and 2,4-dihydroxyacetophenone from $\left[1,2-1^{3} \mathrm{C}_{2}\right]$ acetate. J. Nat. Prod. 1993, 56, 953-956.

36. Holliday, A.E.; Walker, F.M.; Brodie, E.D., III; Formica, V.A. Differences in defensive volatiles of the forked fungus beetle, Bolitotherus cornutus, living on two species of fungus. J. Chem. Ecol. 2009, 35, 1302-1308.

37. Eisner, T. The protective role of the spray mechanism of the Bombardier beetle. J. Insect Physiol. 1958, 2, 215-220.

38. Eisner, T.; Alsop, D.; Hicks, K.; Meinwald, J. Defensive Secretions of Millipeds. In Handbook of Experimental Pharmacology; Bettini, S., Ed.; Springer: Berlin, Germany, 1978; Volume 48, pp. 41-72.

39. Deml, R.; Huth, A. Benzoquinones and hydroquinones in defensive secretions of tropical millipedes. Naturwissenschaften 2000, 87, 80-82.

40. Wu, X.; Buden, D.W.; Attygalle, A.B. Hydroquinones from defensive secretion of a giant Pacific millipede, Acladocricus setigerus (Diplopoda: Spirobolida). Chemoecology 2007, 17, 131-138.

41. Vujisić, L.V.; Makarov, S.E.; Ćurčić, B.P.M.; Ilić, B.S.; Tešević, V.V.; Gođevac, D.M.; Vučković, I.M.; Curčić, S.B.; Mitić, B.M. Composition of the defensive secretion in three species of european millipedes. J. Chem. Ecol. 2011, 37, 1358-1364.

42. Halarnkar, P.P.; Chambers, J.D.; Wakayama, E.J.; Blomquist, G.J. Vitamin $\mathrm{B}_{12}$ levels and propionate metabolism in selected non-insect arthropods and other invertebrates. Comp. Biochem. Physiol. 1987, 88, 869-873.

43. Chu, A.J.; Blomquist, G.J. Biosynthesis of hydrocarbons in insects: Succinate is a precursor of the 
methyl branched alkanes. Arch. Biochem. Biophys. 1980, 201, 304-312.

44. Wakayama, E.D.; Dillwith, J.W.; Howard, R.W.; Blomquist, G.J. Vitamin B $_{12}$ levels in selected insects. Insect Biochem. 1984, 14, 175-179.

45. Halarnkar, P.P.; Blomquist, G.J. Comparative aspects of propionate metabolism. Comp. Biochem. Physiol. 1989, 92B, 227-231.

46. Van den Dool, H.; Kratz, P.D. A generalization of the retention index system including linear temperature programmed gas-liquid partition chromatography. J. Chromatogr. A 1963, 11, 463-471.

47. Schneider, B. Nuclear magnetic resonance spectroscopy in biosynthetic studies. Prog. Nucl. Magn. Reson. Spectrosc. 2007, 51, 155-198.

48. Maier, W.; Shneider, B.; Strack, D. Biosynthesis of sesquiterpenoid cyclohexenone derivatives in mycorrhizal barley roots proceeds via glyceraldehyde 3-phosphate/pyruvate pathway. Tetrahedron Lett. 1998, 39, 521-524.

49. Caetano, D.S.; Machado, G. The ecological tale of Gonyleptidae (Arachnida, Opiliones) evolution: Phylogeny of a Neotropical lineage of armoured harvestmen using ecological, behavioural and chemical characters. Cladistics 2013, doi:10.1111/cla.12009.

50. Cokendolpher, J.C.; Mitov, P.G. Natural Enemies. In Harvestmen: The Biology of Opiliones; Pinto-Da-Rocha, R., Machado, G., Giribet, G., Eds.; Harvard University Press: Cambridge, MA, USA, 2007.

Sample Availability: Samples of the compounds $\mathbf{6}$ and $\mathbf{8}$ are available from the authors.

(C) 2013 by the authors; licensee MDPI, Basel, Switzerland. This article is an open access article distributed under the terms and conditions of the Creative Commons Attribution license (http://creativecommons.org/licenses/by/3.0/). 